\title{
DOUBLE NOR IS NOT A GOOD INDICATOR OF RISK FOR DOWN SYNDROME
}

\author{
Sheng Wang-WuU, Cherng-Kang Perng and Kuang-Dong WuU \\ Institute of Genetics, National Yang Ming Medical College, \\ Taipei, Taiwan
}

\begin{abstract}
Summary The silver staining technique was applied to study the nucleolar organizer regions (NORs) of 38 parents of children with Down syndrome and 40 parents of healthy offspring. Double NOR (dNOR) variants were found in both groups of parents. We compared the incidence of $\mathrm{dNOR}$ between these two groups. Our results indicate that different conclusions can be drawn from the same data depending on how the analyses are carried out. It seems to us that dNOR is not a useful marker for predicting whether or not its carrier is at a higher risk of having children with Down syndrome.
\end{abstract}

\section{INTRODUCTION}

Nucleolar organizer regions (NORs) have recently attracted much attention since double NOR (dNOR), a silver-staining variant of NOR, is claimed to be more frequent among parents of children with trisomy 21 (Jackson-Cook et al., 1985). They calculated that the risk of having children with Down syndrome in families where one of the parents is a dNOR carrier increases by as much as 20 -fold compared to parents without dNOR. It seems that this represents a direct evidence of an association between NORs and trisomy after several decades of searching for the underlying mechanism of chromosome nondisjunction (for review, see Hassold, 1985). On the other hand, several reports contradictory to the statement of Jackson-Cook et al. have subsequently been published (Hassold et al., 1987; Spinner et al., 1989; Schwartz et al., 1989; Serra and Bova, 1990). The conclusion drawn from these latter studies is that a dNOR carrier has no increased risk of having a Down syndrome offspring.

We examined 19 couples who were parents of trisomy 21 children and 20 couples who had healthy offspring. Our results indicate that different conclusions can

Received March 16, 1992; Accepted April 24, 1992. 
be drawn from the same data depending on how the analyses were carried out. This leads us to believe that $\mathrm{dNOR}$ is not a good target for attacking the etiology of Down syndrome.

\section{MATERIALS AND METHODS}

Through the help of the Down's Syndrome Association in Taipei, we obtained blood samples from 19 couples who had one trisomy 21 child. For comparison, blood samples were obtained from 20 couples who had only healthy offspring. These control subjects were either college personnel or from the outpatient clinic of Veterans General Hospital in Taipei.

By using the whole blood technique, cells were cultured for three days in RPMI1640 containing $15 \%$ FBS and $2 \%$ phytohemagglutinin. Colcemid $(0.05$ $\mu \mathrm{g} / \mathrm{ml}$ ) was added to the culture $45 \mathrm{~min}$ before harvesting. The silver staining technique, a modification of Hsu (1981) and Gold and Ellison (1982), is described briefly as follows. One drop of colloid developer ( $2 \%$ gelatin) and three drops of $\mathrm{AgNO}_{3}$ solution $(50 \%)$ were pipetted onto the slide. After mixing these reagents, a coverslip was placed over the slide. The slide was heated on a hot plate at $65^{\circ} \mathrm{C}$ and illuminated with an incandescent lamp (100 W) for 1-2 min, until the color changed from yellow to brown. The coverslip was removed by rinsing with distilled water and the slide was then rinsed immediately with (1) $0.5 \%$ acetic acid; (2) distilled water; (3) $2 \%$ sodium thiosulfate; and (4) distilled water, sequentially. The slides were stained with Giemsa ( $5 \%$ Gerr's in phosphate buffer, $\mathrm{pH} 6.8$ ) for $15 \mathrm{sec}$, rinsed with distilled water and blotted to dry.

Twenty metaphases of each individual were examined by two observers. The NOR status of each acrocentric chromosome was scored and classified under the microscope into one of the four classes: I (two separated NORs along the stalk), II (two NORs not well separated), III (simple NOR of varying sizes), and IV (absence of NOR). Classes I and II were designated as dNOR. Some metaphases were photographed.

In comparing the difference in dNOR incidence between these two groups of parents, we first defined an individual as dNOR positive if either one of 20 cells $(5 \%$ ) (criterion A) or at least $30 \%$ of cells (criterion B) (Spinner et al., 1989; Serra and Bova, 1990) had one or more acrocentric chromosomes with dNOR. We also applied the binomial test for comparing the two proportional samples to the dNOR acrocentric chromosome scores (Kirkwood, 1988).

\section{RESULTS}

Among the 19 couples with trisomic 21 offspring (DS group) and the 20 couples with healthy children (control group), we found 34 individuals with at least one out of 20 cells carrying one or more dNOR-bearing acrocentric chromosomes. These 34 individuals were designated as dNOR positive based on one of our cri- 
teria. The frequencies and distributions of dNOR-positive individuals among the groups and the sexes of the 39 couples are shown in Table 1. The percentage of individuals with dNOR on criterion A was $39.5 \%(15 / 38)$ for the DS group and $47.5 \%(19 / 40)$ for the control group. If we define dNOR positive as an individual with at least $30 \%(6 / 20)$ or more of their cells having dNOR-bearing acrocentric chromosomes, then only five of the 78 examined subjects met this criterion. With the exception of one female subject in the DS group (one D vs. $10 \mathrm{G}$ ), most of the dNOR-bearing acrocentric chromosomes were $\mathrm{D}$ rather than $\mathrm{G}(35 \mathrm{vs}$. 7). The incidence of dNOR positive cases on criterion B was $4 / 38$ (10.5\%) for DS subjects and $1 / 40(2.5 \%)$ for control subjects. The former is 4.2 times that of the latter.

In view of the inconclusive results obtained so far, we applied the binomial test to compare the two proportional samples of dNOR bearing acrocentric chromosomes among the 38 DS subjects and the 40 control subjects. The frequencies of the four classes of NORs among these 78 subjects are given in Table 2. The differences was significant $(\mathrm{p}<0.05)$ for Class $\mathrm{I}$, but not significant for Class II and for I+II. In the course of this study, we found four subjects, three males (two DS and one control) and one female (control), who were heterozygous carriers of a pericentric inversion-inv(9)(p12q13).

Table 1. Distribution of dNOR positive individuals among the 39 couples examined.

\begin{tabular}{llcc}
\hline Group & Sex & \multicolumn{2}{c}{ dNOR positive individuals } \\
Down syndrome & Male & $7 / 19$ & $2 / 19$ \\
& Female & $8 / 19$ & $2 / 19$ \\
\multirow{2}{*}{ Control } & Male & $12 / 20$ & $1 / 20$ \\
& Female & $7 / 20$ & $0 / 20$ \\
\hline
\end{tabular}

* A: criterion A in which individuals with one or more dNOR-positive cells among 20 were considered positive. In criterion $B$, only those with 6 or more positive cells were included. See also text.

Table 2. Distribution and frequencies of the four NOR classes among the 78 subjects examined.

\begin{tabular}{|c|c|c|c|c|c|c|}
\hline \multirow{2}{*}{ Group } & \multirow{2}{*}{$\begin{array}{c}\text { Number of subjects } \\
\text { examined }\end{array}$} & \multicolumn{4}{|c|}{ Classes and frequencies of NOR } & \multirow{2}{*}{$\begin{array}{l}\text { Total number of } \\
\text { acrocentric chro- } \\
\text { mosomes scored }\end{array}$} \\
\hline & & I & II & III & IV & \\
\hline $\begin{array}{l}\text { Down } \\
\text { syndrome }\end{array}$ & 38 & $\begin{array}{c}17 \\
(0.22 \%)\end{array}$ & $\begin{array}{c}43 \\
(0.57 \%)\end{array}$ & $\begin{array}{c}5,878 \\
(77.34 \%)\end{array}$ & $\begin{array}{c}1,662 \\
(21.87 \%)\end{array}$ & 7,600 \\
\hline Control & 40 & $\begin{array}{c}7 \\
(0.09 \%)\end{array}$ & $\begin{array}{c}39 \\
(0.49 \%)\end{array}$ & $\begin{array}{c}6,391 \\
(79.89 \%)\end{array}$ & $\begin{array}{c}1,563 \\
(19.54 \%)\end{array}$ & 8,000 \\
\hline Total & 78 & $\begin{array}{c}24 \\
(0.15 \%)\end{array}$ & $\begin{array}{c}82 \\
(0.53 \%)\end{array}$ & $\begin{array}{c}12,269 \\
(78.65 \%)\end{array}$ & $\begin{array}{c}3,225 \\
(20.67 \%)\end{array}$ & 15,600 \\
\hline
\end{tabular}

Vol. 37, No. 2, 1992 


\section{DISCUSSION}

The results of the present study suggest that dNOR is not a good target for attacking the problem of an association between the presence of this chromosomal variant in a parent and the birth of a trisomic 21 children. There are too many technical and biological variables which confound the conclusions drawn by diferent investigators. The NORs on the short arm stalks of human acrocentric chromosomes have been shown by in situ hybridization to be the sites of genes coding for 18S and 28S ribosomal RNA (Henderson et al., 1972; Evans et al., 1974). Not only do the number of these ribosomal genes vary per chromosome, but also the silver-staining technique identifies neither the rRNA nor the rDNA but only the acidic proteins associated with these sites of rRNA transcription (Ploton et al., 1986). The results depend on the number of genes present, on the level of transcriptional activity and on the stage of the cell cycle in which they are sought (Field et al., 1984; Fakan and Hernandez-Verdum, 1986).

It has been proposed that dNORs may arise from unequal homologous crossing over within the ribosomal genes (Schmickel et al., 1985). Whether the two NOR bodies along the stalk are distinctly separated from each other will depend on the physical sites of the recombination. This may lead to the production of Class I and Class II dNORs (Spinner ef al., 1989) or the production of dNORs and mNORs (Serra and Bova, 1990). It is difficult to be sure that a Class II is really a $d N O R$ and that an $m N O R$ is really not a dNOR. As long as this confusion exists, no reliable conclusion can be reached.

The fact that great intercellular variation in number, class, and morphology of NOR-positive chromosomes exists (Zakharov et al., 1982; Sozansky et al., 1985) makes it difficult to determine if a given subject is dNOR-positive or dNOR-negative. When we apply the criterion $A$, i.e. positive when $5 \%$ or more cells had $\mathrm{dNOR}$, the incidence of dNOR positive individuals in our DS group (39.5\%) was less than that of the control group (47.5\%). If the positive standard were set as $30 \%$ or more cells with dNOR, i.e., criterion B, an opposite conclusion was reached (Table 1). The binomial distribution test tells us another story, the difference for Class I was significant, but not significant for Class IIor Class I+II. All of these data indicate that dNOR is not a useful marker for predicting whether its carrier is at higher risk of having Down syndrome offspring.

Acknowledgments This study was supported by Grant NSC79-0412-BO10-48 from the National Science Council, Taiwan. Thanks is due to Professor Ming-Lai Shen, Biometry Laboratory, National Taiwan University, for his advice and help with the statistical analysis.

\section{REFERENCES}

Evans HJ, Buckland RA, Pardue ML (1974): Location of the genes coding 18S and 28S ribosomal RNA in the human genome. Chromosoma 48: 405-426 
Fakan S, Hernandez-Verdun D (1986): The nucleolus and the nucleolar organizer regions. Biol Cell 56: 189-206

Field DH, Fitzgerald PH, Sin YT (1984): Nucleolar silver-staining patterns related to cell cycle phase and cell generation of PHA-stimulated human lymphocytes. Cytobios 41: 23-33

Gold JR, Ellison JR (1982): Silver staining for nucleolar organizing regions of vertebrate chromosomes. Stain Technol, 58: 51-55

Hassold TJ (1985): The origin of aneuploidy in humans. In: Dellarco VL, Voytek PE, Hollaender A (eds). Aneuploidy: etiology and mechanisons. Basic Life Sciences 36: 103-116, Plenum, New York

Hassold TJ, Jacobs PA, Pettay D (1987): Analysis of nucleolar organizing regions in parents of trisomic spontaneous abortions. Hum Genet 76: 381-384

Henderson AS, Warburton D, Atwood KC (1972): Location of ribosomal DNA in the human chromosome complement. Proc Natl Acad Sci USA 69: 3394-3398

Hsu TC (1981): Polymorphism in human acrocentric chromosomes and the silver staining method for nucleolar organizer regions. Karyogram 7: 45-47

Jackson-Cook CK, Flannery DB, Corey LA, Nance WE, Brown JA (1985): Nucleolar organizer region variants as a risk factor for Down syndrome. Am J Hum Genet 37: 1049-1061

Kirkwood BR (1988): Essentials of medical statistics. Blackwell Scientific Publications, Boston.

Ploton D, Menager M, Jeannesson P, Himber G, Pigeon F, Adnet JJ (1986): Improvement in the staining and in the visualization of the argyrophilic proteins of the nucleolar organizer at the optical level. Histochem J 18: 5-14

Schmickel RD, Gonzales IL, Erickson JM (1985): Nucleolus organizing genes on chromosome 21: recombination and nondisjunction. In: Smith $G(\mathrm{ed})$. Molecular structure of the number 21 chromosome and Down syndrome. Ann NY Acad Sci 450: 121-131

Schwartz S, Roulston D, Cohen MM (1989): Invited Editorial: dNORs and meiotic nondisjunction. Am J Hum Genet 44: 627-630

Serra A, Bova R (1990): Acrocentric chromosome double NOR is not a risk factor for Down syndrome. Am J Med Genet (Suppl) 7: 169-174

Sozansky OA, Zakharov AF, Terekhou SM (1985): Intercellular NOR-Ag-variability in man: II. Search for determining factors, clonal analysis. Hum Genet 69: 151-156

Spinner NB, Eunpu DL, Schmickel RD, Zackai EH, McEldrew D, Bunin GR, McDermid H, Emanuel BS (1989): The role of cytologic NOR variants in the etiology of trisomy 21. Am J Hum Genet 44: 631-638

Zakharov AF, Davudov AZ, Benjush VA, Egolina NA (1982): Polymorphism of Ag-stained nucleolar organizer regions in man. Hum Genet $60: 334-339$ 